\title{
The Combination Effect of Ferulic Acid and Gemcitabine on Expression of Genes Related Apoptosis and Metastasis in PC-3 Prostate Cancer Cells
}

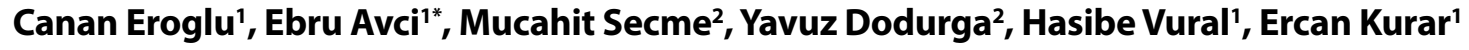 \\ 'Necmettin Erbakan University, Department of Medical Biology, Meram Faculty of Medicine, Konya, Turkey \\ 2Pamukkale University, Department of Medical Biology, Faculty of Medicine, Denizli, Turkey
}

Please cite this article as: Eroglu C, Avci E, Secme M, Dodurga Y, Vural H, Kurar E. The Combination Effect of Ferulic Acid and Gemcitabine on Expression of Genes Related Apoptosis and Metastasis in PC-3 Prostate Cancer Cells. Eur J Biol 2018; 77(1): 32-7.

\begin{abstract}
Objective: Prostate cancer is the second most common cause of cancer-related deaths in men. Nowadays, new treatment approaches have been tested for cancer therapy including natural compounds with low toxicity. Ferulic acid (FA) is known as an abundant phenolic compound found in various fruits and vegetables. As a potent antioxidant, the anticarcinogenic effect of FA has been demonstrated in various cancer cell lines. The objective of this study was to investigate the combined effect of FA and gemcitabine on apoptosis and metastasis in PC-3 human prostate cancer cell lines.

Materials and Methods: Cell viability was determined using the XTT method after the cells were treated with gemcitabine or FA and gemcitabine. According to the results of cytotoxicity assays, PC-3 cells were treated with <IC50 doses of combination ( $200 \mu \mathrm{M}$ FA and $35 \mu \mathrm{M}$ gemcitabine) and IC50 dose of gemcitabine. Expressions of genes that are important in apoptosis and metastasis pathways were evaluated in dose and control groups by qPCR.

Results: According to the results, the combination of FA and gemcitabine affected the expression of more genes in apoptosis and metastasis with a higher fold change compared with the single treatment of gemcitabine in PC-3 human prostate cancer cell lines.
\end{abstract}

Conclusion: Our study indicates that FA can be an effective part of the combination treatments.

Keywords: Ferulic acid, gemcitabine, PC-3 cell line

\section{INTRODUCTION}

Prostate cancer is one of the most prevalent types of cancer in men with the highest mortality rate together with lung and colorectal cancer, especially in industrialized countries (1). When prostate cancer is diagnosed at an early stage, stage 1 and 2, the 5-year survival rate can reach $90 \%$, while the likelihood of successful treatment at advanced stages such as stage 3 and 4 is low (2). Digital rectal examination (DRE) and measurements of prostate-specific antigen (PSA) level are often used for the diagnosis of early-stage prostate cancer, but these methods are inadequate because of low specificity (3). Androgen is one of the most important risk factors for the development of prostate cancer, so androgen deprivation therapy (ADT) is widely used as the main treatment method as well as surgery and radiation therapy $(4,5)$. When patients don't respond to the
ADT for a long time, chemotherapeutic approaches are applied in treatment (6). Unfortunately, resistance to treatments is eventually seen in most of the patients, and, for this reason, new therapeutic strategies are needed for the treatment of prostate cancer.

It is known that more than $60 \%$ of anticancer drugs currently used are derived from natural sources (7). Therefore, the development of more effective chemotherapeutic agents from natural products and the investigation of the abilities of inducing apoptosis or cancer prevention by different mechanisms are the most important focus points in cancer studies. The findings of research illustrated that various natural products had protective effects and could inhibit carcinogenesis by regulating the expressions of genes in apoptosis, invasion, angiogenesis and metastasis pathways (8). 
Ferulic acid (FA; 4-hydroxy-3-methoxycinnamic acid), is a caffeic acid derivative found in vegetables, fruit, some beverages (for example, coffee and beer) and is an effective component of some Chinese medicinal herbs, for instance, Angelica sinensis, Cimicifuga racemosa and Ligusticum chuangxiong (9). It has been reported that FA has various pharmacological effects including antioxidant, antimicrobial, antiinflammatory, antithrombotic and antihypercholesterolemic effects (10-14). Moreover, the anticancer effect of FA has been demonstrated through studies involving various cancer cell lines and its anticancer activity is attributed to an antioxidant property which is associated with its phenolic nucleus and unsaturated side chain (15). It has been shown that FA has cytotoxic effects on cancer cells and affects important processes such as apoptosis, cell cycle and metastasis in the studies conducted with human breast cancer (MCF-7), human pancreatic cancer, human prostate cancer (PC-3 and LNCAP), human lung cancer (H1299) and human osteosarcoma (143B and MG63) (16-20). However, little is known about its effectiveness as a part of the combination therapies in cancer treatment (21).

In studies involving the investigation of anticancer properties of natural products, demonstration of their apoptotic and anti-metastatic effects is a priority. The apoptosis process, which is an important part of the mechanism that regulates the death or survival of the cell, is controlled by various signaling pathways (22). The apoptosis pathway is divided into three categories (i) the pathway of death receptor or extrinsic induced by death receptors, (ii) the intrinsic or mitochondrial pathway, and (iii) the perforin/granzyme pathway which is induced by granzyme $A$ and granzyme $B$ from cytotoxic T cells (23). It is important that chemotherapeutic agents have inhibiting capabilities to prevent invasion and metastasis in prostate cancer cells in addition to inducing apoptosis because bone metastasis occurs in $80 \%$ of advanced prostate cancer patients and is one of the main causes of prostate cancer related deaths $(24,25)$. Tumor metastasis is a multistep process that includes the development of new blood vessels, detachment of metastatic cells from the primary tumor, invasion to stroma, intravasation to the blood and lymphatic vessels and extravasation to the target organ and growth of secondary tumor (26). All these steps are mediated by different factors and, especially, molecules involved in cellcell and cell-matrix interaction, and the proteases responsible for the degradation of extracellular matrix components which are the most important participants in this process (27).

Gemcitabine is a deoxycytidine analog that exhibits anticancer activity against various solid tumors such as pancreatic cancer, lung cancer and prostate cancer $(28,29)$. It is also thought that gemcitabine can be part of combination therapies based on the phase studies involving combinations with various chemotherapeutic agents in prostate cancer $(30,31)$. The aim of this study is to investigate the combined effect of FA and gemcitabine on apoptosis and metastasis by evaluating the expression levels of genes important in apoptosis and metastasis in PC-3 prostate cancer cell lines.

\section{MATERIAL AND METHODS}

\section{Cell Culture}

A PC-3 (ATCC ${ }^{\circledast}$ CRL-1435 ${ }^{\mathrm{TM}}$ ) human prostate cancer cell line, obtained from the ATCC (Manassass,VA, USA), was cultured in RPMI-1640 medium containing $2 \mathrm{mM} \mathrm{L-glutamine} \mathrm{supplement-}$ ed with $10 \% \mathrm{FBS}$ and $1 \%$ penicillin/streptomycin at $37^{\circ} \mathrm{C}$ in a humidified atmosphere of $5 \% \mathrm{CO}_{2}-95 \%$ air. FA and gemcitabine were purchased from Sigma-Aldrich Chemical Company (USA).

\section{Cytotoxicity Assay}

The cytotoxic effects of gemcitabine and its combination with FA on PC-3 cells were determined by XTT (2,3-Bis-(2-Methoxy-4-Nitro-5Sulfophenyl)-2H-Tetrazolium-5-Carboxanilide) assay. The cells (1×10 cells/well) were seeded into 96-well plates and incubated for $24 \mathrm{~h}$. The cells were treated with 0-70 $\mu \mathrm{M}$ gemcitabine for $48 \mathrm{~h}$ after the incubation. And then XTT solution was added to each well and incubated at $37^{\circ} \mathrm{C}$ for $4 \mathrm{~h}$. The absorbance was read at $450 \mathrm{~nm}$ (reference wavelength $630 \mathrm{nM}$ ) in a microplate reader. The concentration of gemcitabine which inhibited $50 \%$ of cell viability $\left(\mathrm{IC}_{50}\right)$ was determined. The combination doses were detected according to $\mathrm{IC}_{50}$ doses of gemcitabine and FA. IC $C_{50}$ dose of FA was previously indicated by Eroglu et al. (18). Then cells were treated with gemcitabine and FA at various concentration (0-150 $\mu \mathrm{M}$ doses and 0-900 $\mu \mathrm{M}$ doses, respectively). According to the combined effect of gemcitabine and FA on cell viability, two groups were formed for subsequent experiments. Therefore, PC-3 cells were treated with $200 \mu \mathrm{M}$ FA and $35 \mu \mathrm{M}$ gemcitabine $\left(<\mathrm{IC} \mathrm{C}_{50}\right.$ doses), and $50 \mu \mathrm{M}$ gemcitabine $\left(\mathrm{IC}_{50}\right.$ dose $)$ for $48 \mathrm{~h}$.

\section{RNA Isolation and qPCR Analysis}

Total RNAs were extracted from PC-3 cells using TRlzol Reagent and reverse transcription was performed using iScript ${ }^{\mathrm{TM}} \mathrm{CDNA}$ Synthesis Kit (Bio-Rad) according to the manufacturer's instructions.

The primer sequences of target and reference genes were designed using IDT PrimerQuest (https://eu.idtdna.com/site). Primers used in the qPCR reaction are presented in Table 1. The effects of FA and, gemcitabine on apoptosis and metastasis were evaluated using qPCR (Biorad CFX Connect). Each qPCR mix was set up in $20 \mu \mathrm{l}$ final volume containing $10 \mu \mathrm{l} 2 \mathrm{X}$ SYBR Green Master Mix, $5 \mathrm{pMol}$ of each primer and $1 \mu \mathrm{l}$ cDNA. The following PCR profile was used: denaturation at $95^{\circ} \mathrm{C}$ for $10 \mathrm{~min}$, followed by 35 cycles consisting of denaturation at $95^{\circ} \mathrm{C}$ for $30 \mathrm{~s}$, annealing at $60^{\circ} \mathrm{C}$ for $30 \mathrm{~s}$, and extension at $72^{\circ} \mathrm{C}$ for $30 \mathrm{~s}$.

\section{Statistical Analysis}

The gene expressions analysis of the groups was determined by using the $2^{-\triangle \Delta C T}$ method. The volcano plot analysis, from $\mathrm{RT}^{2}$ Profiles ${ }^{\text {TM }}$ PCR Array Data Analysis, which is assessed statistically using Student's t test, was used in the comparison of the groups.

\section{RESULTS}

\section{Anti-proliferative Effects of Gemcitabine and Combination of Gemcitabine and FA in PC-3 Cells}

The cytotoxic effects of gemcitabine and combination of gemcitabine and FA were determined using the XTT assay. Gemcitabine inhibited the cell viability of PC-3 cells in a dose depen- 
Table 1. Primers sequences used $q P C R$ analysis

\begin{tabular}{|c|c|}
\hline Gene & Primer sequence \\
\hline \multirow[t]{2}{*}{ GAPDH } & F:5-TGAACGGGAAGCTCACTGG-3 \\
\hline & R:5-TCCACCACCCTGTTGCTGTA-3 \\
\hline \multirow[t]{2}{*}{ CASP3 } & F:5-GAGCCATGGTGAAGAAGGAATA-3 \\
\hline & R:5-TCAATGCCACAGTCCAGTTC-3 \\
\hline \multirow[t]{2}{*}{ CASP7 } & F:5-CGAAACGGAACAGACAAAGATG-3 \\
\hline & R:5-TTAAGAGGATGCAGGCGAAG-3 \\
\hline \multirow[t]{2}{*}{ CASP8 } & F:5-GCCCAAACTTCACAGCATTAG-3 \\
\hline & R:5-GTGGTCCATGAGTTGGTAGATT-3 \\
\hline \multirow[t]{2}{*}{ CASP9 } & F:5-CGACCTGACTGCCAAGAAA-3 \\
\hline & R:5-CATCCATCTGTGCCGTAGAC-3 \\
\hline \multirow[t]{2}{*}{$\mathrm{BCL} 2$} & F:5- GTGGATGACTGAGTACCTGAAC-3 \\
\hline & R:5- GAGACAGCCAGGAGAAATCAA-3 \\
\hline \multirow[t]{2}{*}{ BAX } & F:5- GGAGCTGCAGAGGATGATTG-3 \\
\hline & R:5- GGCCTTGAGCACCAGTTT-3 \\
\hline \multirow[t]{2}{*}{ FAS } & F:5- GTGATGAAGGACATGGCTTAGA-3 \\
\hline & R:5- GCCCAAACTTCACAGCATTAG-3 \\
\hline \multirow[t]{2}{*}{ CYCS } & F:5- GGAGAGGATACACTGATGGAGTA-3 \\
\hline & R:5- GTCTGCCCTTTCTTCCTTCTT-3 \\
\hline \multirow[t]{2}{*}{ TNF } & F:5- CСТCСТСТСТGCCATCAAG-3 \\
\hline & R:5- CCAGATAGATGGGCTCATACC-3 \\
\hline \multirow[t]{2}{*}{ PPARG } & F:5-TGGGTGAAACTCTGGGAGAT-3 \\
\hline & R:5- AAGTTGGTGGGCCAGAATG-3 \\
\hline \multirow[t]{2}{*}{ MMP-2 } & F:5-TGGCAGTGCAATACCTGAA-3 \\
\hline & R:5-GCATGGTCTCGATGGTATTCT-3 \\
\hline \multirow[t]{2}{*}{ MMP-9 } & F:5-GCAGACATCGTCATCCAGTT-3 \\
\hline & R:5-ACAACTCGTCATCGTCGAAAT-3 \\
\hline \multirow[t]{2}{*}{ TIMP-1 } & F:5-GCGTTATGAGATCAAGATGACCA-3 \\
\hline & R:5-AACTCCTCGCTGCGGTT-3 \\
\hline \multirow[t]{2}{*}{ TIMP-2 } & F:5-GCTGCGAGTGCAAGATCA-3 \\
\hline & R:5-CTCTTGATGCAGGCGAAGAA-3 \\
\hline \multirow[t]{2}{*}{$\mathrm{CDH} 1$} & F:5-GAGAGCGGTGGTCAAAGAG-3 \\
\hline & R:5-AGCTGGCTCAAGTCAAAGT-3 \\
\hline \multirow[t]{2}{*}{$\mathrm{CDH} 2$} & F:5-GCTGACCAGCCTCCAAC-3 \\
\hline & R:5-CATGTGCCCTCAAATGAAACC-3 \\
\hline \multirow[t]{2}{*}{ COL4A2 } & F:5-AAGTACAGCTTCTGGCTGAC-3 \\
\hline & R:5-AGCGGCTGATGTGTGTG-3 \\
\hline \multirow[t]{2}{*}{ VEGFA } & F:5-CGCAGACAGTGCTCCAG-3 \\
\hline & R:5-CACCCAAGACAGCAGAAAGT-3 \\
\hline \multirow[t]{2}{*}{ HIF1A } & F:5-ACCCTCTGATTTAGCATGTAGAC-3 \\
\hline & R:5-TTCACCCTGCAGTAGGTTTC-3 \\
\hline
\end{tabular}

dent manner as shown in Figure 1. The $\mathrm{IC}_{50}$ dose of gemcitabine was found to be $50 \mu \mathrm{M}$ in the PC-3 cell line for $48 \mathrm{~h}$ and the $\mathrm{IC}_{50}$ dose of FA have been determined as $300 \mu \mathrm{M}$ in the PC-3 cell line for $48 \mathrm{~h}$ in a previous study (18).

For determining the cytotoxic effect of combinations, cells were treated with gemcitabine and FA simultaneously for $48 \mathrm{~h}$ at various concentrations. The combination of gemcitabine and FA inhibited the cell viability of PC-3 cells in a dose dependent manner as shown in Figure 2. Considering these results, combination doses used for subsequent experiments were determined as $35 \mu \mathrm{M}$ gemcitabine and $200 \mu \mathrm{M}$ FA. The PC -3 cells were treated to $\mathrm{IC}_{50}$ doses of gemcitabine and combination $<\mathrm{IC}_{50}$ doses of both for $48 \mathrm{~h}$.

\section{Effects of Gemcitabine and FA on Expressions of Genes As- sociated with Apoptosis}

The effects of gemcitabine and combination of FA and gemcitabine on expressions of genes are important in apoptosis including CASP3, CASP7, CASP8, CASP9, BCL2, BAX, FAS, CYCS, TNF and $P P A R G$, and were determined using qPCR analysis, after total RNA isolation and CDNA synthesis from control and dose group cells.

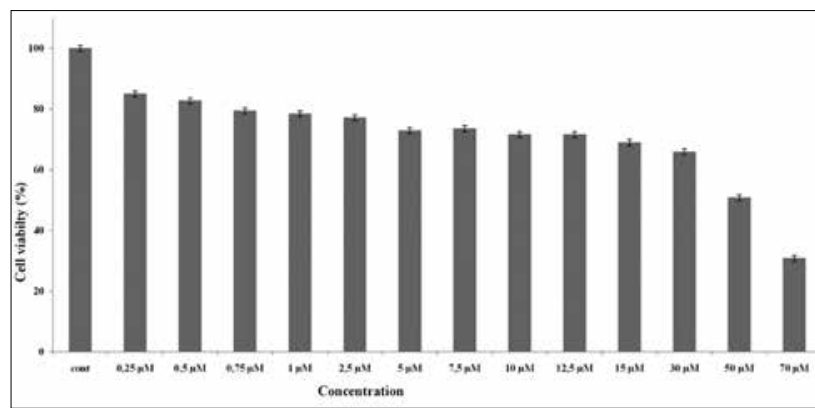

Figure 1. Effect of gemcitabine on the viability of PC-3 cells for $48 \mathrm{~h}$. The cells were treated with gemcitabine with different concentrations for $48 \mathrm{~h}$ and cell proliferation was determined by XTT assay. The IC 50 dose of gemcitabine was found to be 50 $\mu \mathrm{M}$ for $48 \mathrm{~h}$ in the PC-3 cell line. The data is the average results of three independent experiments.

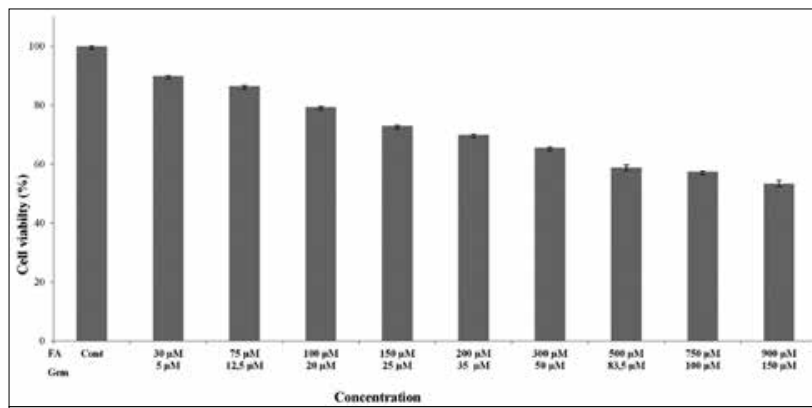

Figure 2. The combined effect of gemcitabine and FA on the viability in PC-3 cells for $48 \mathrm{~h}$. The cells were treated with gemcitabine and FA with different concentrations for $48 \mathrm{~h}$ and the cytotoxic effect of combination doses was determined by XTT assay. The data is the average results of three independent experiments. 


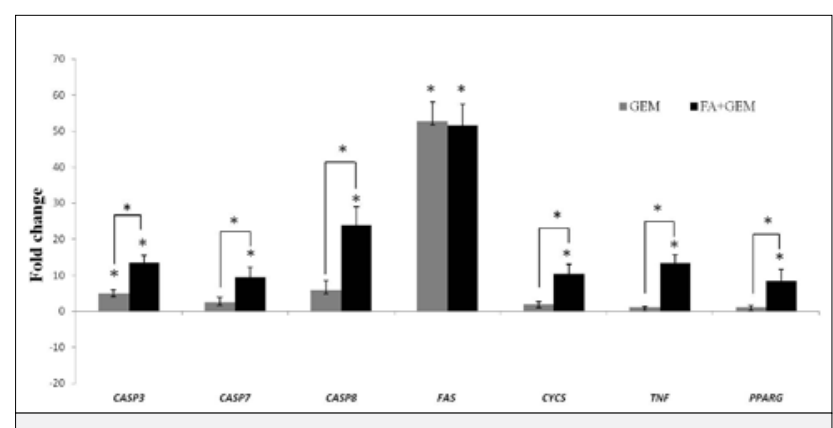

Figure 3. The effect of gemcitabine and FA on the expression of important genes in apoptosis for $48 \mathrm{~h}$. Values represent the mean \pm SD of three independent experiments. ${ }^{*} p<0.05$.

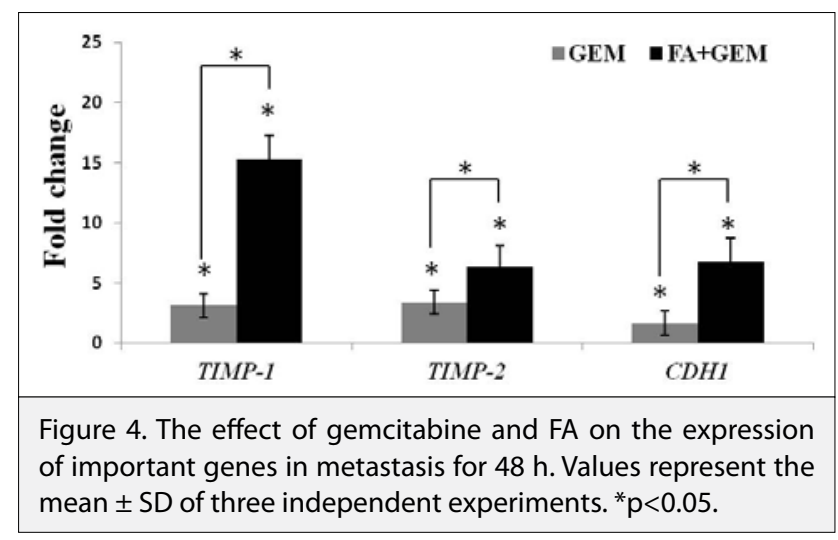

According to the $\mathrm{qPCR}$ results, when the cells were treated with the $I C_{50}$ dose of gemcitabine, the expression of CASP3 (5.01 fold) and FAS (52.8 fold) genes were significantly upregulated. After the treatment with a combination of FA and gemcitabine, significant increases in the expression of CASP3, CASP7, CASP8, FAS, CYCS, TNF and PPARG were observed as 13.55, 9.48, 23.83, $51.63,10.34,17.86$ and 14.63 folds, respectively compared with the control group $(\mathrm{p}<0.05)$. On the other hand, CASP3, CASP7, CASP8, CYCS, TNF and PPARG expressions were significantly elevated in combination treatment when compared with the gemcitabine treatment $(p<0.05)$ (Figure 3).

\section{Effects of Gemcitabine and FA on Expressions of Genes As- sociated with Metastasis}

After the treatment with gemcitabine or combination of FA and gemcitabine, the expression levels of important genes associated with metastasis including MMP-2, MMP-9, TIMP-1, TIMP-2, $C D H 1, C D H 2, C O L 4 A 2, V E G F$ and HIF1A were determined using qPCR analysis.

As shown in Figure 4, after the treatment with gemcitabine, the expressions of TIMP-1 (3.13 fold), TIMP-2 (3.41 fold) and CDH1 ( 1.66 fold) genes were significantly elevated compared with the control group. On the other hand, a significant increase in the expression of TIMP-1, TIMP-2 and CDH1 genes was observed when a combination of gemcitabine and FA was used as 14.24, 6.30 and 6.73 folds, respectively $(p<0.05)$. Furthermore, significant changes in expressions of TIMP-1, TIMP-2 and CDH1 genes were determined in combination treatment compared with the gemcitabine treatment $(p<0.05)$. No significant change was observed in the other genes.

\section{DISCUSSION}

It is known that the consumption of vegetables, fruits, whole grains reduces the incidence of chronic diseases and various cancers especially stomach, esophagus, lung, oral cavity, pancreatic and colon $(32,33)$. The anticancer activities of these foods are associated with the phenolic compounds which are secondary metabolites with a common aromatic ring possessing one or more hydroxyl group $(34,35)$.

Various studies, including those on prostate cancer, have shown that phenolic compounds can induce apoptosis by affecting important signaling pathways or can inhibit invasion and metastasis. Furthermore, some of these compounds have been found to have a synergistic effect with chemotherapeutic agents used in standard therapy (36-38). According to these results, the investigation of the anticancer properties of natural compounds by cell culture and animal studies has become an important focus for the development of new therapeutic strategies against cancer.

FA, a natural phytochemical which is found in rice, wheat, barley, orange, coffee, apple and peanuts, was investigated for its possible synergistic effect with gemcitabine on prostate cancer cells in present study $(39,40)$. Although there is only a limited number of studies investigating the synergistic effect of FA with various agents in cancer, previous literature illustrated that FA can be part of the combination therapies in various situations. For example, Pan et al. reported that FA and Z-ligustilide which is another major component of Angelica sinensis, have a synergistic effect on cold-induced vasospasm by regulating cold-sensing proteins TRPM8 and TPRA1 (41). Another study indicated that low doses of FA combined with a subthreshold dose of piperine, a bioavailability enhancer, have synergistic antidepressant-like effect on depression-like behaviors in mice (42). Canturk has shown that FA exhibits a synergistic anticandidal and apoptotic effects in combination with caspofungin against $C$. albicans (43). The potential protective effect of FA on splenic toxicity was investigated and it has been reported that its combination with ascorbic acid has a significant recuperative effect on aniline induced spleen toxicity in rats (44). The effectiveness of FA in combination treatments has also been demonstrated in studies with cancer cells. The combination of FA and $\delta$-tocotrienol ( $\delta$-T3), another important component of rice bran, significantly reduces the proliferation of human prostate carcinoma, human breast adenocarcinoma and human pancreatic carcinoma cells as compared to single treatment (45). Likewise, in another study, the same researchers demonstrated that the combination of FA and $\delta$-T3 significantly decreases cellular telomerase activity in colorectal adenocarcinoma cells. Moreover, it was thought that FA increases the bioavailability of $\delta$-T3 (46). In a study conducted with breast cancer cells, it was shown that FA renders cancer cells more hypersensitive to ABT-888, poly 
(ADP-ribose) polymerase (PARP) inhibitors, compared to stand alone treatment of ABT-888 (21).

In this study, to demonstrate the efficacy of FA in combination therapy, a combination dose was primarily determined considering the $\mathrm{IC}_{50}$ doses of FA and gemcitabine. The cytotoxic effect of gemcitabine in PC-3 cell lines was detected in a time- and dose-dependent manner using the XTT method. The $\mathrm{IC}_{50}$ dose of gemcitabine in PC-3 was found to be $50 \mu \mathrm{M}$ for $48 \mathrm{~h}$. IC ${ }_{50}$ doses of FA have been determined as $300 \mu \mathrm{M}$ for the same period in a previous study. Then, combination doses were determined at lower concentrations to demonstrate the possible additive or synergistic effect of FA and gemcitabine in PC-3 cells. After the treatment of the prescribed doses to the cells, expressions of genes, which are important in apoptosis and metastasis, were analyzed in dose and control groups.

Apoptosis, described as a physiological process, plays an important role in the maintenance of hemostasis and the control of the cell proliferation in normal tissue. It is known that defects that occur in this mechanism cause cancer development (47). Molecules involved in this process are important for demonstrating the efficacy of newly developed agents. In the present study, the expressions of genes coding of molecules in both intrinsic and extrinsic pathways of apoptosis have been analyzed. According to the results, in the group treated with gemcitabine, the expressions of CASP3 and FAS genes significantly increased. After the treatment with A combination of FA and gemcitabine, a significant increase was observed in the expressions of CASP3, CASP7, CASP8, FAS, CYCS, TNF and PPARG genes compared with the control group $(\mathrm{p}<0.05)$. In addition, the increases in the expressions of CASP3, CASP7, CASP8, CYCS, TNF and PPARG genes are significant compared with the gemcitabine treatment. According to the results, it can be concluded that the combination treatment affected expression of more genes in apoptosis compared with the single treatments in PC-3 human prostate cancer cell line.

Epithelial to mesenchymal transition (EMT), a biological process in which polarized epithelial cells undergo various biochemical changes resulting in increased cell migration, invasiveness and resistance to apoptosis, is the most important stage of metastasis (48). At this stage, there is a decrease in the expressions of various epithelial junction proteins such as E-cadherin, a-catenin, and $\gamma$-catenin; while, there is an increase in nonepithelial cadherins such as $\mathrm{N}$-cadherin (49). In addition, various enzyme groups, especially matrix metalloproteases (MMP), contribute to this process by destroying the extracellular matrix components (50). In this study, the anti-metastatic effect of FA and gemcitabine was investigated by analyzing the expression levels of gene encoding molecules that are important in the EMT process. According to the results, the expression of TIMP-1, TIMP-2 and $C D H 1$ genes significantly increased after the gemcitabine treatment compared with the control group. Likewise, after the treatment with a combination of FA and gemcitabine, a significant increase in the expression of TIMP-1, TIMP-2 and CDH1 genes was found compared with the control group $(p<0.05)$.
However, the increases in the expression of genes were higher than single treatments of gemcitabine. Moreover, the increases in the expressions of TIMP-1, TIMP-2 and CDH1 genes are significant compared with the gemcitabine treatment.

Chemotherapeutic agents are known to be toxic and have serious side effects. Natural products may exhibit a synergistic effect with the agents used in the treatment as well as reducing these side effects. In the present study, we demonstrated for the first time that a combination of FA with gemcitabine, an agent used in standard therapy, synergistically inhibited apoptosis and metastasis by regulating genes associated with these processes in prostate cancer cells. These results show that FA can promotes efficacy of gemcitabine in prostate cancer cells and FA can be an effective part of the combination treatments.

Conflict of Interest: The authors have no conflict of interest to declare.

\section{REFERENCES}

1. Siegel RL, Miller KD, Jemal A. Cancer statistics, 2016. CA Cancer J Clin 2016; 66(1):7-30. [CrossRef]

2. Trewartha $D$, Carter K. Advances in prostate cancer treatment. Nat Rev Drug Discov 2013; 12(11):823-4. [CrossRef]

3. Scher HI, Leibel SA, Fuks Z, Cordon-Cardo C, Scardino PT. Cancers of the prostate. DeVita VT Jr, Hellman S, Rosenberg SA, editors. 7th ed. Philadelphia, PA: Lippincott Williams \& Wilkins; 2005.

4. Wilt TJ, MacDonald R, Rutks I, Shamliyan TA, Taylor BC, Kane RL. Systematic review: comparative effectiveness and harms of treatments for clinically localized prostate cancer. Ann Intern Med 2008; 148(6):435-48. [CrossRef]

5. Moe EL, Chadd J, McDonagh M, Valtonen M, Horner-Johnson W, Eden $\mathrm{KB}$, el al. Exercise interventions for prostate cancer survivors receiving hormone therapy: Systematic review. Translational Journal of the ACSM 2017; 2(1):1-9.

6. Botrel TE, Clark O, Lima Pompeo AC, Horta Bretas FF, Sadi MV, Ferreira $U$, et al. Efficacy and safety of combined androgen deprivation therapy (ADT) and docetaxel compared with ADT alone for metastatic hormone-naive prostate cancer: A systematic review and meta-analysis. PLoS One 2016; 11(6):e0157660. [CrossRef]

7. Newman DJ, Cragg GM. Natural products as sources of new drugs over the 30 years from 1981 to 2010. J Nat Prod 2012; 75(3):311-35. [CrossRef]

8. Safe S, Kasiappan R. Natural products as mechanism-based anticancer agents: $\mathrm{Sp}$ transcription factors as targets. Phytother Res 2016; 30(11):1723-32. [CrossRef]

9. Mancuso C, Santangelo R. Ferulic acid: pharmacological and toxicological aspects. Food Chem Toxicol 2014; 65:185-95. [CrossRef]

10. Ou S, Kwok KC. Ferulic acid: pharmaceutical functions, preparation and applications in foods. J. Sci. Food. Agric 2004; 84:1261-9. [CrossRef]

11. Trombino S, Serini S, Di Nicuolo F, Celleno L, Andò S, Picci N, et al. Antioxidant effect of ferulic acid in isolated membranes and intact cells: synergistic interactions with alpha-tocopherol, beta-carotene, and ascorbic acid. J Agric Food Chem 2004; 52(8):2411-20. [CrossRef]

12. Borges A, Ferreira C, Saavedra MJ, Simões M. Antibacterial activity and mode of action of ferulic and gallic acids against pathogenic bacteria. Microb Drug Resist 2013; 19(4):256-65. [CrossRef] 
13. Zhu H, Liang QH, Xiong XG, Chen J, Wu D, Wang Y, et al. Anti-inflammatory effects of the bioactive compound ferulic acid contained in Oldenlandia diffusa on collagen-induced arthritis in rats. Evid Based Complement Alternat Medn 2014; 2014:573801.

14. Hong Q, Ma ZC, Huang H, Wang YG, Tan HL, Xiao CR, et al. Antithrombotic activities of ferulic acid via intracellular cyclic nucleotide signaling. Eur J Pharmacol 2016; 777:1-8. [CrossRef]

15. Shahidi $F$, Chandrasekara A. Hydroxycinnamates and their in vitro and in vivo antioxidant activities. Phytochem Rev 2010; 9(1):147170. [CrossRef]

16. Serafim TL, Carvalho FS, Marques MP, Calheiros R, Silva T, Garrido J, et al. Lipophilic caffeic and ferulic acid derivatives presenting cytotoxicity against human breast cancer cells. Chem Res Toxicol 2011; 24(5):763-74. [CrossRef]

17. Thakkar A, Chenreddy S, Wang J, Prabhu S. Ferulic acid combined with aspirin demonstrates chemopreventive potential towards pancreatic cancer when delivered using chitosan-coated solid-lipid nanoparticles. Cell Biosci 2015; 5:46. [CrossRef]

18. Eroğlu C, Seçme M, Bağcı G, Dodurga Y. Assessment of the anticancer mechanism of ferulic acid via cell cycle and apoptotic pathways in human prostate cancer cell lines. Tumour Biol 2015; 36(12):9437-46. [CrossRef]

19. Fong $\mathrm{Y}$, Tang CC, Hu HT, Fang HY, Chen BH, Wu CY, et al. Inhibitory effect of trans-ferulic acid on proliferation and migration of human lung cancer cells accompanied with increased endogenous reactive oxygen species and $\beta$-catenin instability. Chin Med 2016;11:45. [CrossRef]

20. Wang T, Gong X, Jiang R, Li H, Du W, Kuang G. Ferulic acid inhibits proliferation and promotes apoptosis via blockage of PI3K/Akt pathway in osteosarcoma cell. Am J Transl Res 2016; 8(2):968-80.

21. Choi YE, Park E. Ferulic acid in combination with PARP inhibitor sensitizes breast cancer cells as chemotherapeutic strategy. Biochem Biophys Res Commun 2015; 458(3):520-4. [CrossRef]

22. Kalimuthu S, Se-Kwon K. Cell survival and apoptosis signaling as therapeutic target for cancer: marine bioactive compounds. Int J Mol Sci 2013; 14(2):2334-54. [CrossRef]

23. Elmore S. Apoptosis: A review of programmed cell death. Toxicol Pathol 2007; 35(4):495-516. [CrossRef]

24. Coleman RE. Clinical features of metastatic bone disease and risk of skeletal morbidity. Clin Cancer Res 2006;1 2(20 Pt 2):6243-9.

25. Sturge J, Caley MP, Waxman J. Bone metastasis in prostate cancer: Emerging therapeutic strategies. Nat Rev Clin Oncol 2011;8(6):35768. [CrossRef]

26. Guan X. Cancer metastases: Cehallenges and opportunities. Acta Pharm Sin B 2015; 5(5):402-18. [CrossRef]

27. Jiang WG, Sanders AJ, Katoh M, Ungefroren H, Gieseler F, Prince M, et al. Tissue invasion and metastasis: Molecular, biological and clinical perspectives. Semin Cancer Biol 2015; 35:244-75. [CrossRef]

28. Wong A, Soo RA, Yong WP, Innocenti F. Clinical pharmacology and pharmacogenetics of gemcitabine. Drug Metab Rev 2009; 41(2):77-88. [CrossRef]

29. Huang CY, Chang YJ, Luo SD, Uyanga B, Lin FY, Tai CJ, et al. Maspin mediates the gemcitabine sensitivity of hormone-independent prostate cancer. Tumour Biol 2016; 37(3):4075-82. [CrossRef]

30. Di Lorenzo G, Autorino R, Giuliano M, Morelli E, Giordano A, Napodano $\mathrm{G}$, et al. Phase II trial of gemcitabine, prednisone, and zoledronic acid in pretreated patients with hormone refractory prostate cancer. Urology 2007; 69(2):347-51. [CrossRef]

31. Lee JL, Ahn JH, Choi MK, Kim Y, Hong SW, Lee KH, et al. Gemcitabine-oxaliplatin plus prednisolone is active in patients with cas- tration-resistant prostate cancer for whom docetaxel-based chemotherapy failed. Br J Cancer 2014; 110(10):2472-8. [CrossRef]

32. Reddy L, Odhav B, Bhoola KD. Natural products for cancer prevention: A global perspective. Pharmacol Ther 2003; 99:1-13. [CrossRef]

33. Liu RH. Health-promoting components of fruits and vegetables in the diet. Adv Nutr 2013; 4(3):384S-92S. [CrossRef]

34. Arts IC, Hollman PC. Polyphenols and disease risk in epidemiologic studies. Am J Clin Nutr 2005; 81:317S-25S. [CrossRef]

35. Russell W, Duthie G. Plant secondary metabolites and gut health: the case for phenolic acids. Proc Nutr Soc 2011; 70:389-96. [CrossRef]

36. Syed DN, Khan N, Afaq F, Mukhtar H. Chemoprevention of prostate cancer through dietary agents: progress and promise. Cancer Epidemiol Biomarkers Prev 2007; 16(11):2193-203. [CrossRef]

37. Singh CK, George J, Ahmad N.Resveratrol-based combinatorial strategies for cancer management. Ann N Y Acad Sci 2013; 1290:113-21. [CrossRef]

38. Anantharaju PG, Gowda PC, Vimalambike MG, Madhunapantula SV. An overview on the role of dietary phenolics for the treatment of cancers. Nutr J 2016; 15(1):99. [CrossRef]

39. Chowdhury S, Ghosh S, Rashid K, Sil PC. Deciphering the role of ferulic acid against streptozotocin-induced cellular stress in the cardiac tissue of diabetic rats. Food Chem Toxicol 2016; 97:187-98. [CrossRef]

40. Li H, Wang Y, Fan R, Lv H, Sun $\mathrm{H}$, Xie H, et al. The effects of ferulic acid on the pharmacokinetics of warfarin in rats after biliary drainage. Drug Des Devel Ther 2016; 10: 2173-80. [CrossRef]

41. Pan Y, Zhao G, Cai Z, Chen F, Xu D, Huang S, et al. Synergistic effect of ferulic acid and Z-Ligustilide, major components of $A$. sinensis, on regulating cold-sensing protein TRPM8 and TPRA 1 in vitro. Evid Based Complement Alternat Med 2016; 2016: 3160247. [CrossRef]

42. Li G, Ruan L, Chen R, Wang R, Xie X, Zhang M, et al. Synergistic antidepressant-like effect of ferulic acid in combination with piperine: involvement of monoaminergic system. Metab Brain Dis 2015; 30(6):1505-14. [CrossRef]

43. Canturk Z. Evaluation of synergistic anticandidal and apoptotic effects of ferulic acid and caspofungin against Candida albicans. J Food Drug Anal 2017; 1-5.

44. Rahman H, Upaganlawar A, Upasani C. Protective effect of ferulic ccid alone and in combination with ascorbic acid on aniline induced spleen toxicity. Ann Pharmacol Pharm 2017; 2(1): 1012.

45. Eitsuka T, Tatewaki N, Nishida H, Kurata T, Nakagawa K, Miyazawa T. Synergistic inhibition of cancer cell proliferation with a combination of $\delta$-tocotrienol and ferulic acid. Biochem Biophys Res Commun 2014;453(3):606-11. [CrossRef]

46. Eitsuka T, Tatewaki N, Nishida H, Nakagawa K, Miyazawa T. A Combination of $\delta$-tocotrienol and ferulic acid synergistically inhibits telomerase activity in DLD-1 human colorectal adenocarcinoma cells. J Nutr Sci Vitaminol (Tokyo) 2016; 62(5):281-7. [CrossRef]

47. Goldar S, Khaniani MS, Derakhshan SM, Baradaran B. Molecular mechanisms of apoptosis and roles in cancer development and treatment. Asian Pac J Cancer Prev 2015; 16(6):2129-44. [CrossRef]

48. Kalluri R, Weinberg RA. The basics of epithelial-mesenchymal transition. J Clin Invest 2009; 119(6):1420-8. [CrossRef]

49. Tsai JH, Yang J. Epithelial-mesenchymal plasticity in carcinoma metastasis. Genes Dev 2013; 27(20):2192-206. [CrossRef]

50. Jacob A, Prekeris R. The regulation of MMP targeting to invadopodia during cancer metastasis. Front Cell Dev Biol 2015;3:4. [CrossRef] 